ББК 63.4

\author{
Организация конференциии и издание материалов проведень \\ при финансовой поддержке Российского фонда фундаментальных исследований, \\ проект № 19-09-20008
}

Утверждено к печати Ученым советом ИИМК РАН

Редакционная коллегия тома I: В. А. Алёкшин, Л. Б. Кирчо (отв. редакторы),

В. П. Никоноров, В. Я. Стёганцева; В. В. Терёхина

Рецензенты: д. и. н. Л. Б. Вишняцкий, д. и. н. А. А. Выборнов

Программный комитет конференции: академик РАН, д. и. н., проф. М. Б. Пиотровский

(Государственный Эрмитаж, почетный председатель); д. и. н. В. А. Лапшин (ИИМК РАН, председатель); д. и. н. А. В. Головнёв (МАЭ РАН, сопредседатель); д. и. н. В. А. Дергачёв (Высшая антропологическая школа, Молдова, сопредседатель); д. и. н. И. Ф. Попова (ИВР РАН, сопредседатель); академик АН Республики Узбекистан, д. и. н., проф. Э. В. Ртвеладзе (сопредседатель); к. и. н. А. В. Поляков (ИИМК РАН, зам. председателя); к. и. н. В. А. Алёкшин (ИИМК РАН, зам. председателя); д. и. н. Ю. Е. Берёзкин (МАЭ РАН); Dr., Prof. Н. Бороффка (Германский археологический институт, Германия); В. С. Бочкарёв (ИИМК РАН); Dr. Э. Кайзер (Свободный университет Берлина, Германия); к. и. н. М. Т. Кашуба (ИИМК РАН); д. и. н. Л. Б. Кирчо (ИИМК РАН); к. и. н. А. В. Кияшко (Южный федеральный университет); к. и. н. П. Ф. Кузнецов (СГСПУ);

к. и. н. Н. М. Малов (СНИГУ); к. и. н. В. П. Никоноров (ИИМК РАН); Ю. Ю. Пиотровский

(Государственный Эрмитаж); д. и. н., проф. Д. Г. Савинов (Институт истории СПбГУ);

к. и. н. В. Н. Седых (Институт истории СПбГУ); к. и. н. Н. Н. Скакун (ИИМК РАН);

к. и. н. Н. Ф. Соловьёва (ИИМК РАН); к. и. н. А. И. Торгоев (Государственный Эрмитаж); к. и. н. Е. А. Черлёнок (Институт истории СПбГУ)

Организационный комитет конференции: к. и. н. А. В. Поляков (ИИМК РАН, председатель);

к. и. н. В. А. Алёкшин (ИИМК РАН, зам. председателя); В. С. Бочкарёв (ИИМК РАН); ); к. и. н. М. Т. Кашуба (ИИМК РАН); д. и. н. Л. Б. Кирчо (ИИМК РАН);

А. И. Климушина (ИИМК РАН, отв. секретарь); к. и. н. В. П. Никоноров (ИИМК РАН); Ю. Ю. Пиотровский (Государственный Эрмитаж); В. Я. Стёганцева (ИИМК РАН); В. В. Терёхина

(ИИМК РАН, МАЭ РАН, отв. секретарь); к. и. н. Е. С. Ткач (ИИМК РАН); И. Ж. Тутаева (Государственный Эрмитаж); к. и. н. Е. А. Черлёнок (Институт истории СПбГУ)

Древности Восточной Европы, Центральной Азии и Южной Сибири в контексте связей и взаимодействий в евразийском культурном пространстве (новые данные и концепции): Материалы Международной конференции, 18-22 ноября 2019 г., Санкт-Петербург. Т. I. Древняя Центральная Азия в контексте евразийского культурного пространства (новые данные и концепции). К 90-летию со дня рождения патриарха евразийской археологии Вадима Михайловича Массона. - СПб.: ИИМК РАН, Невская Типография, 2019. — 291 с.

ISBN 978-5-907053-34-2

DOI 10.31600/978-5-907053-34-2 
Массон В. М. 1989. Первые цивилизации. Л.

Массон В. М. 2006. Культурогенез Древней Центральной Азии. СПб.

\title{
THE STUDY OF THE ANCIENT HISTORY OF AFGHANISTAN IN THE WORKS BY VADIM M. MASSON
}

\author{
Rakhmonali Y. Sharifov \\ Tajik National University, Dushanbe, Tajikistan
}

Keywords: agricultural cultures, civilizations, archaeological investigations, Afghanistan, India, Iran

The paper analyzes of the works by Vadim M. Masson, which are devoted to the archaeology and ancient history of Afghanistan. In them he has considered the basic questions of cultural genesis and the formation of the earliest centers of agricultural cultures, the resettlement of peoples and the emergence of great civilizations in the country and adjacent territories. Based on the fact that the region has been little studied archaeologically, however, a large number of monuments have been discovered, ranging from the Stone Age to the Late Middle Ages, it has been concluded that Afghanistan was always at the epicenter of events of all the historical eras, and there were cultural ties between the civilizations of India and Central Asia and the Middle East.

\section{ВНУТРЕННЯЯ ХРОНОЛОГИЯ И ПЕРИОДИЗАЦИЯ ГОНУР-ДЕПЕ}

\author{
Р. М. Сатаев ${ }^{\star}$, Н. А. Дубова ${ }^{\star}$ М. А. Мамедов ${ }^{\star *}$ \\ ${ }^{\star}$ Институт этнологии и антропологии РАН, Москва, Россия; ${ }^{* *}$ Академия художеств, \\ Ашхабад, Туркменистан
}

DOI: 10.31600/978-5-907053-34-2-40-41

Ключевые слова: бронзовый век, Южный Туркменистан, Древняя Маргиана, Гонур-депе, хронология, периодизаиия.

Гонур-депе, предполагаемый административно-культовый центр Древней Маргианы, расположен в 85 км к северу от г. Байрамали (Марыйский велаят Туркменистана). Результаты радиоуглеродного анализа показывают, что временные рамки существование Гонурдепе определяются в пределах 2500-1500 гг. до н. э. (Зайцева и др. 2008: 179; Fontugne et al. In print), хотя внутренняя периодизация памятника остается слабо разработанной.

В. И. Сарианиди выделял три этапа функционирования протогородского центра. Однако во дворце Гонура он и Б. Н. Удеумурадов кроме трех горизонтов, отражающих периоды застройки и перепланировки дворца, отмечали следы более ранних и более поздних конструкций (Удеумурадов 1996; Сарианиди 1998). На основании находок ранних стен В. И. Сарианиди предполагал, что «подобно келлелийскому оазису, и в гонурском имелись недолговечные строения, относящиеся к рубежу IV-III тыс. до н. э.» (Сарианиди 1998: 2). Следы использования участка после руинизации дворца проявляются обрывками стен и гончарными печами, впущенными в руины предшествующих периодов (Сарианиди 1996: 1-2).

В связи с необходимостью уточнения и конкретизации этих данных в периферийной северной и восточной части дворца были проведены исследования по выяснению стратиграфического положения и особенностей устройства сохранившихся стен. В 2014-2018 гг. здесь было обследовано и описано 50 разрезов-расчисток, выявлены новые строительные объекты.

Обобщая данные первых исследователей Гонура и наших стратиграфических исследований, можно говорить о наличии здесь пяти строительных горизонтов (пяти периодов).

\footnotetext{
1 Работа выполнена при финансовой поддержке РФФИ, проект «Древности» № 18-09-40082.
} 
1. От основания поселения до возведения дворца ( 2500/2300-2000 гг. до н. э.) 1-й строительный горизонт дворца («додворцовый» горизонт).

2. От возведения дворца до «большого пожара» во дворце ( 2000-1900 гг. до н. э.) 2-й строительный горизонт дворца («І дворцовый» горизонт).

3. От начала восстановления дворца после пожара до прекращения функционирования дворца как резиденции правителей Гонура - ухода правящей элиты ( 1900-1700 гг. до н. э.) - 3-й строительный горизонт дворца («II дворцовый» горизонт).

4. От времени ухода правящей элиты и начала использования дворца простыми общинниками (перепланировки помещений дворца для собственных нужд) до его полного запустения ( 1700-1600 гг. до н. э.) - 4-й строительный горизонт дворца («III дворцовый» горизонт).

5. От времени запустения дворца до полного оставления людьми территории протогородского центра ( 1600-1500 гг. до н. э.) - 5-й строительный горизонт дворца («постдворцовый» горизонт).

\section{Литература}

Зайцева Г. И., Дубова Н. А., Семенцов А. А., Реймар П., Мэллори Дж., Юнгнер Х. 2008. Радиоуглеродная хронология памятника Гонур Депе // Сарианиди В. И. (ред.). Тр. МарАЭ. М. T. 2. C. $166-179$.

Сарианиди В. И. 1996. Отчет о работах Маргианской археологической экспедиции в 1996 г. // Архив МарАЭ.

Сарианиди В. И. 1998. Отчет о работах на Гонур-депе в 1998 г. // Там же.

Сарианиди В. И. 2007. Дворцово-храмовый комплекс Северного Гонура // РА. № 1. С. 49-63.

Удеумурадов Б. Н. 1996. Некоторые итоги // Архив МарАЭ. Рукопись.

Fontugne M., Zajtseva G. I., Lyonnet B., Dubova N. A., Burova N. D. In print. Appendix. Radiocarbon dates related to the BMAC-Oxus Civilization. In: Lyionet B., Dubova N. (eds.). Oxus Civilization. London.

\section{THE INTERNAL CHRONOLOGY AND PERIODIZATION OF GONUR DEPE}

Robert M. Sataev ${ }^{\star}$ Nadezhda A. Dubova ${ }^{\star}$, Muhamed A. Mamedov**

${ }^{*}$ Institute of Ethnology and Anthropology of the Russian Academy of Sciences, Moscow, Russia;

${ }^{*}$ Academy of Arts, Ashgabat, Turkmenistan

Keywords: Bronze Age, Southern Turkmenistan, Ancient Margiana, Gonur Depe, chronology and periodization.

Gonur Depe is the administrative and religious centre of Ancient Margiana, the ruins of which are located in $85 \mathrm{~km}$ to the north of the town of Bayramaly (Turkmenistan). The time frame for the existence of Gonur Depe is defined in the range of 2500-1500 years BC. Summarizing the data of the first researchers of Gonur Depe and our stratigraphic studies, conducted in 2014-2018, one can talk about the presence there of five periods (construction horizons) of the functioning of this proto-city center:

1. from the foundation of the settlement to the construction of the palace ( 2500/2300-2000 BC);

2. from the construction of the palace to the "big fire" in the palace ( 2000-1900 BC);

3. from the beginning of the restoration of the palace after the fire until it ceased to function as a residence of the rulers of Gonur Depe ( 1900-1700 BC);

4. from the time of the departure of the ruling elite and the use of the palace by the common members until its complete desolation ( 1700-1600 BC);

5. from the time of the desolation of the palace to the complete abandonment of this territory by the people ( 1600-1500 BC). 